\title{
Pengaruh Pendidikan Kewirausahaan, Self Efficacy, Locus of Control dan Karakter Wirausaha Terhadap Minat Berwirausaha
}

\author{
Aprilda Yanti \\ Program Studi Magister Manajemen, Universitas Muhammadiyah Sumatera Utara Medan, Indonesia \\ Jl. Denai No. 217, Tegal Sari Mandala II, Medan Denai, Kota Medan, Sumatera Utara 20371 \\ Email: aprildayanti90@gmail.com
}

\begin{abstract}
Abstrak. Tujuan dari penelitian ini untuk menganalisis pengaruh pendidikan kewirausahaan, self efficacy, Locus of Control dan karaketer wirausaha pada minat berwirausaha mahasiswa Strata-1 Universitas Muhammadiyah Sumatera Utara. Sampel yang digunakan sebanyak 125 orang. Penelitian menggunakan teknik Random Sampling serta pengumpulan data dengan kuisioner. Teknik analisis data yang digunakan adalah uji asusmsi klasik, regresi linear berganda, uji-t , uji-f dan koefisien determinan. Hasil penelitian menunjukkan bahwa secara parsial pendidikan kewirausahaan tidak berpengaruh signifikan terhadap minat berwirausaha. Secara parsial self efficacy berpengaruh signfikan terhadap minat berwirausaha. Locus of Control tidak berpengaruh signifikan terhadap minat berwirausaha. Secara karakter wirausaha berpengaruh signfikan terhadap minat berwirausaha. Secara simultan, simultan terdapat pengaruh positif dan signifikan pendidikan kewirausahaan, self efficacy, Locus of Control dan karakter wirausaha terhadap minat berwirausaha mahasiswa Fakultas Ekonomi dan Bisnis Universitas Muhammadiyah Sumatera Utara.
\end{abstract}

Kata Kunci: Pendidikan kewirausahaan, self efficacy, Locus of Control, karaketer wirausaha, minat berwirausaha

\begin{abstract}
The purpose of this study was to analyze the effect of entrepreneurship education, self-efficacy, Locus of Control and entrepreneurial characteristics on the interest of entrepreneurship students of the University of University of Muhammadiyah Sumatera Utara. The sample used was 125 people. The study uses random sampling techniques and data collection by questionnaire. The data analysis technique used is the classic assumption test, multiple linear regression, $t$-test, f-test and determinant coefficient. The results showed that partially entrepreneurship education had no significant effect on entrepreneurial interest. Partially self efficacy has a significant effect on the interests of entrepreneurship. Locus of Control has no significant effect on entrepreneurial interest. In character, entrepreneurship has a significant effect on entrepreneurial interest. Simultaneously, there is a positive and significant influence of entrepreneurship education, self-efficacy, Locus of Control and entrepreneurial character toward the entrepreneurial interest of students of the Faculty of Economics and Business, University of Muhammadiyah Sumatera Utara
\end{abstract}

Keywords : Entrepreneurship education, self efficacy, Locus of Control, entrepreneurial characteristics, interest in entrepreneurship

\section{PENDAHULUAN}

Pengangguran dan kemiskinan masih merupakan masalah besar yang dihadapi oleh bangsa Indonesia sekarang ini dan beberapa tahun kedepan. Tingginya angka pengangguran merupakan masalah yang tidak ada habisnya di Indonesia. Masalah pengangguran merupakan masalah yang dihadapi oleh setiap negara. Selama beberapa dekade angka pengangguran telah mengalami kenaikan. Krisis ekonomi 1998 juga telah ikut menyumbangkan angka pengangguran. Di Indonesia angka pengangguran terbanyak justru diciptakan oleh kelompok terdidik.

Entrepreneur saat ini merupakan sebuah alternatif yang dapat dijadikan solusi bagi penyelesaian permasalahan sempitnya lapangan pekerjaan. Memberikan bekal entrepreneur 
kepada mahasiswa merupakan salah satu upaya membangun kemandirian mahasiswa. Disadari betul bahwa jumlah lulusan perguruan tinggi setiap tahunnya meningkat dan tidak semua lulusan tersebut dapat terserap oleh dunia kerja, sehingga memberikan pemahaman yang jelas tentang bagaimana pentingnya berwirausaha itu kepada mahasiswa.

Tabel 1. Pengangguran di Indonesia Berdasarkan Tingkat Pendidikan 2014-2018

\begin{tabular}{clccccc}
\hline No & $\begin{array}{l}\text { Pendidikan Tertinggi } \\
\text { Yang Ditamatkan }\end{array}$ & $\mathbf{2 0 1 4}$ & $\mathbf{2 0 1 5}$ & $\mathbf{2 0 1 6}$ & $\mathbf{2 0 1 7}$ & $\mathbf{2 0 1 8}$ \\
\hline 1 & $\begin{array}{l}\text { Tidak/belum pernah } \\
\text { sekolah }\end{array}$ & 74.898 & 55.554 & 59.346 & 62.984 & 42.039 \\
\hline 2 & Tidak/belum tamat SD & 389.550 & 371.542 & 384.069 & 404.435 & 446.812 \\
\hline 3 & SD & 1.229 .652 & 1.004 .961 & 1.035 .731 & 904.561 & 967.630 \\
\hline 4 & SLTP & 1.566 .838 & 1.373 .919 & 1.294 .483 & 1.274 .417 & 1.249 .761 \\
\hline 5 & SLTA Umum/SMU & 1.962 .786 & 2.280 .029 & 1.950 .626 & 1.910 .829 & 1.650 .636 \\
\hline 6 & SLTA Kejuruan/SMK & 1.332 .521 & 1.569 .690 & 1.520 .549 & 1.621 .402 & 1.424 .428 \\
\hline 7 & Akademi/Diploma & 193.517 & 251.541 & 219.736 & 242.937 & 300.845 \\
\hline 8 & Universitas & 495.143 & 653.586 & 567.235 & 618.758 & 789.113 \\
\hline$\quad$ Total & $\mathbf{7 . 2 4 4 . 9 0 5}$ & $\mathbf{7 . 5 6 0 . 8 2 2}$ & $\mathbf{7 . 0 3 1 . 7 7 5}$ & $\mathbf{7 . 0 0 5 . 2 6 2}$ & $\mathbf{6 . 8 7 1 . 2 6 4}$ \\
\hline
\end{tabular}

Sumber: www.bps.go.id (2018)

Berdasarkan tabel diatas data terakhir menunjukkan bahwa jumlah penganggur terdidik di Indonesia yang telah menamatkan pendidikan diploma dan sarjana sampai dengan 2018 telah mencapai 1.090 .000 orang meningkat pada tahun sebelumnya yang berjumlah 862.000 orang. (bps.go.id, 2018). Jumlah penggauran terbuka untuk wilayah sumatera utara mencapai 396.000 orang pada periode 2018 meningkat dari tahun sebelumnya yang berjumlah 377.000 orang atau 5,04\% (sumut.bps.go.id, 2018) .

Menurut Napitupulu, (2009) kemampuan berwirausaha harus dibangun secara sadar dari usia dini dengan demikian generasi muda juga mulai menjadikan wirausaha sebagai salah satu pilihan karier yang penting untuk mendukung kesejahteraan bangsa dimasa akan datang. Menurut (Fatoki, 2014), sekolah bisnis dapat menjadi jembatan antara pengetahuan teoritis dan keterlibatan praktis di lapangan. Terkait dengan pengaruh pendidikan kewirausahaan, perlu adanya pemahaman tentang bagaimana dan mendorong lahirnya wirausaha-wirausaha muda yang potensial sementara mereka berada dibangku pendidikan. Chimucheka, (2013), menyatakan bahwa salah satu faktor pendorong pertumbuhan kewirausahaan di suatu negara terletak pada peranan universitas melalui penyelenggaraan pendidikan kewirausahaan. Menurut (Ramayah \& Harun, 2005), minat berwirausaha adalah tendensi keinginan individu untuk melakukan tindakan wirausaha dengan menciptakan produk baru melalui peluang bisnis dan pengambilan risiko. Kegiatan kewirausahaan sangat ditentukan oleh minat individu itu sendiri. Orang-orang tidak akan menjadi pengusaha secara tiba-tiba tanpa pemicu tertentu. Pendidikan kewirausahaan menjadi faktor penting dalam menumbuhkan dan mengembangkan keinginan, jiwa dan prilaku berwirausaha dikalangan generasi muda karena pendidikan merupakan sumber sikap dan minat keseluruhan untuk menjadi wirausahawan sukses di masa depan (Fatoki, 2014). Chen, Greene, \& Crick, (1998) menjelaskan entrepreneurial self efficacy adalah keyakinan individu tentang kemampuan diri sendiri untuk membuka bisnis baru serta mengelola tugas dan terlibat dalam peluncuran bisnis baru tersebut. Menurut Kreitner \& Kinicki, (2008) Locus of Control terdiri dari dua konstruk yaitu internal dan eksternal, dimana internal Locus of Control apabila seseorang meyakini bahwa apa yang terjadi selalu berada dalam kontrolnya dan dia selalu mengambil peran serta bertanggung jawab dalam setiap pengambilan keputusan, sedangkan external Locus of Control apabila seseorang meyakini bahwa kejadian dalam hidupnya berada diluar kontrolnya.

Menurut Baharuddin, (2009), karakter adalah suatu keadaan jiwa yang tampak dalam tingkah laku dan perbuatan sebagai akibat pengaruh pembawaan dan lingkungan. Dengan kata lain, karakter tergantung pada kekuatan dari luar (eksogen). Jadi, karakter individu dipengaruhi 
oleh pembawaan dan lingkungan. Karakter dapat diubah dan dididik. Universitas Muhammadiyah Sumatera Utara adalah salah satu Universitas terbesar dikota medan yang setiap tahunya melahirkan lulusan baru dengan jumlah mahasiswa yang lulus setiap tahunnya kurang lebih 2.000 orang/tahun. Sebagai salah satu lembaga pendidikan di Provinsi Sumatera Utara, Universitas Muhammadiyah Sumatera Utara telah mendukung terciptanya wirausaha muda dengan memberikan mata kuliah kewirausahaan mulai dari semester 3 sampai dengan semester 7 pada Program Studi Manajemen Fakultas Ekonomi dan Bisnis yang ada di Universitas Muhammadiyah Sumatera Utara. Penulis ingin melihat apakah setelah menerima pendidikan kewirausahaan minat berwirausaha mahasiswa akan meningkat atau sebaliknya.

\section{LANDASAN TEORI}

\section{Minat Berwirausaha}

Minat merupakan ketertarikan seseorang terhadap sesuatu.Minat juga dapat menjadi suatu motivasi bagi seseorang untuk melakukan sesuatu (Yusnandar, 2017). Minat pada dasarnya merupakan penerimaan akan suatu hubungan antara diri sendiri dengan sesuatu di luar diri semakin kuat atau dekat hubungan tersebut semakin besar minat (Slameto, 2010). Menurut Winkel, (2004), minat yaitu kecenderungan yang menetap pada seseorang untuk merasa tertarik pada suatu bidang tertentu dan merasa senang dalam berbagai kegiatan yang berkaitan dengan bidang itu sendiri. Sedangkan menurut Walgito, (2004) minat merupakan suatu keadaan dimana individu menaruh perhatian pada sesuatu dan disertai dengan keinginannya untuk mengetahui dan mempelajari serta membuktikan lebih lanjut mengenai situasi tersebut.

Menurut Purwanto, (2007) minat adalah perbuatan yang berpusat kepada suatu tujuan dan merupakan suatu dorongan bagi perbuatan itu sendiri”. Dalam diri manusia terdapat motif yang mendorong manusia untuk berinteraksi dengan dunia luar. Mengembangkan minat terhadap sesuatu pada dasarnya adalah membantu mahasiswa/mahasiswi melihat bagaimana hubungan antara materi diharapkan. Untuk dipelajarinya dengan dirinya sendiri sebagai individu. Proses ini berarti menunjukkan pada mahasiswa/mahasiswi bagaimana pengetahuan tertentu mempengaruhi dirinya, melayani tujuan-tujuannya, dan memuaskan kebutuhan-kebutuhannya (Slameto, 2010).

Wirausaha memiliki arti menjalankan usaha. Menurut Tedjasutisna, (2004), wirausaha adalah orang-orang yang mempunyai kemampuan melihat dan menilai kesempatan-kesempatan bisnis, mengumpulkan sumber-sumber data yang dibutuhkan guna mengambil keuntungan dan tindakan yang tepat guna dalam memastikan kesuksesan. Menurut Suryana, (2013) wirausaha adalah orang yang melakukan upaya-upaya kreatif dan inovatif dengan jalan mengembangkan ide, dan meramu sumber daya untuk menemukan peluang (Opportunity) dan perbaikan (Preparation) hidup. Sedangkan menurut Alma, (2013) wirausaha adalah orang yang mendobrak sistem ekonomi yang ada dengan memperkenalkan barang dan jasa baru dengan menciptakan bentuk organisasi baru atau mengolah bahan baku. Orang tersebut melakukan kegiatannya melalui organisasi bisnis yang baru atau dapat dilakukan dalam organisasi bisnis yang sudah ada. Menurut Meredith, (2002) berwirausaha adalah memadukan perwatakan pribadi, keuangan dan sumber daya, sehingga, berwirausaha merupakan suatu pekerjaan atau karier yang harus bersifat fleksibel dan imajinatif, mampu merencanakan, mengambil resiko, mengambil keputusan-keputusan dan tindakan-tindakan untuk mencapai tujuan.

Dalam penelitian ini, peneliti menggunakan alat ukur aspek-aspek tingkah laku tertentu yang mungkin terjadi dari ungkapan yang disebabkan motivasi tertentu dengan indikator unsur-unsur minat oleh Abror, (2013), yaitu: minat mengandung unsur kognisi (pengenalan), emosi (perasaan) dan konasi (hasrat atau motivasi). Unsur kognisi artinya minat didahului 
dengan perkenalan terlebih dahulu dengan obyek yang diminati, yang ditunjukan dengan pengetahuan kewirausahaan dan pengalaman mahasiswa/mahasiswi untuk berwirausaha, dalam hal ini obyek yang diminati adalah harapan atau keinginan mahasiswa/mahasiswi untuk berwirausaha.

Unsur emosi, maksudnya dalam partisipasi setelah pengenalan disertai dengan ketertarikan dan perasaan tertentu yang biasanya perasaan senang dan ditunjukan dengan menaruh perhatian lebih terhadap minat berwirausaha pada mahasiswa/mahasiswi. Unsur konasi merupakan kelanjutan dari kedua unsur sebelumnya yang diwujudkan dengan hasrat dalam bentuk keinginan, usaha dan keyakinan. Dengan demikian minat untuk berwirausaha dapat diukur melalui 3 (tiga) macam indikator sebagai berikut: 1) Kognisi, yang meliputi: pengetahuan kewirausahaan terhadap minat berwirausaha, 2) Emosi, yang meliputi: perasaan senang, ketertarikan dan perhatian terhadap minat berwirausaha, dan 3) Konasi, yang meliputi: keinginan, usaha dan keyakinan terhadap minat berwirausaha.

\section{Pendidikan Kewirausahaan}

Pendidikan kewirausahaan adalah aktivitasaktivitas pengajaran dan pembelajaran tentang kewirausahaan yang meliputi pengembangan pengetahuan, ketrampilan, sikap dan karakter pribadi sesuai dengan umur dan perkembangan siswa (Isrososiawan, 2013). Pendidikan kewirausahaan adalah proses pengetahuan akan kegiatan membuka bisnis dengan menanamkan jiwa kewirausahaan agar mereka dapat menjadi wirausaha yang berbakat (Alma, 2013). Menurut Wibowo \& Pramudana (2016), pendidikan kewirausahaaan merupakan caracara atau upaya untuk menumbuhkan jiwa dan mental kewirausahaan bagi seseorang melalui institusi pendidikan maupun institusi lain, seperti lembaga pelatihan, training, dan sebagainya. Sedangkan menurut Prihantoro (2015), pendidikan kewirausahaan bertujuan untuk membentuk manusia secara utuh sebagai insan yang memiliki sebuah karakter, pemahaman, dan keterampilan. Pendidikan kewirausahaan secara umum adalah proses pendidikan yang menerapkan prinsipprinsip dan metodologi ke arah pembentukan kecakapan hidup (life skill) pada anak didiknya melalui kurikulum terintegrasi yang dikembangkan di lingkungan pendidikan.

Tujuan pendidikan kewirausahaan menurut Alma (2013) yaitu: mengetahui peranan usaha dalam perekonomian, mengetahui karakteristik usaha dan proses kewirausahaan, dapat membuat perencanaan usaha dan pengembangan usaha, mampu melihat adanya peluang bisnis, paham akan konsep ilmu kewirausahaan. Menurut Mulyani (2011), mengintegrasikan nilai-nilai kewirausahaan melalui pendidikan kewirausahaan dan peneliti mengambil nilai tersebut sebagai indikator penilaian pendidikan kewirausahaan, antara lain: Kreatif, Inovatif, Mandiri, Realistis dan Komunikatif. Hasil penelitian sebelumnya yang mengkaji pendidikan kewirausahaan, menyatakan bahwa mahasiswa yang berpengalaman mengembangkan berbagai ketrampilan teknis dan pelatihan lebih percaya diri menjadi wirausaha (Chen, Weng, \& Hsu, 2010). Tetapi, hasil penelitian Cheng et al., (2009) menyatakan bahwa pengetahuan kewirausahaan dan minat memulai usaha tidak berhubungan secara signifikan, karena metode pembelajaran kewirausahaan yang digunakan tidak efektif

\section{Efikasi Diri}

Efikasi diri yaitu kepercayaan (persepsi) individu mengenai kemampuan untuk membentuk suatu perilaku berwirausaha. Efikasi diri diukur dengan skala (Gaddam, 2008). Efikasi diri berbeda dengan aspirasi (cita-cita), karena cita-cita menggambarkan sesuatu yang ideal yang seharusnya dapat dicapai, sedang efikasi menggambarkan penilaian kemampuan diri (Alwisol, 2009). Baron \& Byrne, (2004) menyatakan bahwa efikasi diri adalah evaluasi 
seseorang terhadap kemampuan atau kompetisinya untuk melakukan sebuah tugas, mencapai tujuan atau mengatasi hambatan. Selanjunya Selanjutnya Kilapong (2013) dalam (Mujiatun, Jufrizen, \& Ritonga, 2019) menyatakan bahwa self-efficacy merupakan kepercayaan pada kapasitas dirinya untuk mencapai kesuksesan pada pekerjaan dan tanggung jawabnya. Semakin sering seseorang melakukan evaluasi diri dan menganggap bahwa dia memiliki banyak kemampuan yang positif, semakin besar pula efikasi yang dimilikinya. Efikasi diri mempengaruhi secara kuat motivasi individu untuk memperoleh keberhasilan atau tujuan yang ingin dicapai. (Feist, Feist, \& Roberts, 2013) mendefinisikan efikasi diri sebagai keyakinan diri untuk mengetahui kemampuannya sehingga dapat melakukan suatu bentuk konrol terhadap manfaat orang itu sendiri dan kejadian dalam lingkungan sekitarnya.

Efikasi diri dapat mendorong kinerja seseorang dalam berbagai bidang termasuk minat berwirausaha (Luthans, 2010). Oleh karena itu, dalam membuka suatu usaha diperlukan keyakinan diri (self efficacy) terhadap kemampuannya agar usahanya dapat berhasil. Hal yang sama juga diungkapkan oleh Robbins \& Judge (2011), efikasi diri juga dikenal dengan teori kognitif sosial atau penalaran sosial yang merujuk pada keyakinan individu bahwa dirinya mampu menjalankan suatu tugas.

Menurut Bandura (2009), ada beberapa faktor penting yang mempengaruhi efikasi diri. Jadi bisa dibilang efikasi diri adalah keyakinan seseorang mengenai sejauh mana ia mampu mengerjakan tugas, mencapai tujuan, dan merencanakan tindakan untuk mencapai suatu goal. Efikasi diri merupakan faktor yang dapat berfungsi sebagai penentu bagaimana seseorang berpikir, merasakan, memotivasi dirinya, dan bereaksi terhadap situasi yang dihadapinya (Bandura, 2009). Indikator yang digunakan untuk mengukur efikasi diri yaitu kepercayaan diri akan kemampuan mengelola usaha, kepemimpinan sumber daya manusia, kematangan mental dalam usaha, dan merasa mampu memulai usaha (Gaddam, 2008).

\section{Locus of Control}

Locus of Control menurut Kreitner \& Kinicki, (2008), terdiri dari dua konstruk yaitu internal dan eksternal, dimana internal Locus of Control apabila seseorang meyakini bahwa apa yang terjadi selalu berada dalam kontrolnya dan dia selalu mengambil peran serta bertanggung jawab dalam setiap pengambilan keputusan, sedangkan eksternal Locus of Control apabila seseorang meyakini bahwa kejadian dalam hidupnya berada diluar kontrolnya. Setiap individu bervariasi dalam banyaknya kewajiban pribadi yang mereka tanggung untuk setiap perilaku mereka dan konsekuensinya. Rotter, (1990) mengidentifikasi suatu dimensi kepribadian yang ia beri nama Locus of Control (lokus pengendalian) untuk menjelaskan perbedaan - perbedaan ini. Ia berpendapat bahwa orang cenderung menghubungkan peyebab dari perilaku terutama pada diri mereka sendiri atau faktor lingkungan. Ciri kepribadian ini menghasilkan pola perilaku yang berbeda, (Kreitner \& Kinicki, 2014). Sedangkan, menurut Robbins \& Judge, (2011), Locus of Control merupakan tingkat dimana individu yakin bahwa mereka adalah penentu nasib mereka sendiri.

Konsep internal Locus of Control dan eksternal Locus of Control secara lebih lebih rinci dikemukakan oleh Lee-Kelley, (2006), Locus of Control internal diartikan sebagai keyakinan seseorang bahwa didalam dirinya tersimpan potensi besar untuk menentukan nasib sendiri, tidak peduli apakah lingkungannya akan mendukung atau tidak mendukung. Individu seperti ini memiliki etos kerja yang tinggi, tabah menghadapi segala macam kesulitan baik dalam kehidupannya maupun dalam pekerjaannya. Di sisi lain, individu yang eksternal Locus of Control-nya cukup tinggi akan mudah pasrah dan menyerah jika sewaktu-waktu terjadi persoalan yang sulit. Individu semacam ini akan memandang masalah- masalah yang sulit sebagai ancaman bagi dirinya, bahkan terhadap orang- orang yang berada disekelilingnya pun 
dianggap sebagai pihak yang secara diam-diam selalu mengancam eksistensinya. Bila mengalami kegagalan dalam menyelesaikan persoalan, maka individu semacam ini akan menilai kegagalan sebagai semacam nasib dan membuatnya ingin lari dari persoalan.

Mereka yang yakin dapat mengendalikan tujuan mereka dikatakan memiliki Locus of Control internal, sedangkan yang memandang hidup mereka dikendalikan oleh kekuatan pihak luar disebut memiliki Locus of Control eksternal (Robbins, 2004). Internal kontrol mengacu pada persepsi terhadap kejadian baik positif maupun negatif sebagai konsekuensi dari tindakan ataupun perbuatan sendiri dan berada di bawah pengendalian dirinya. Eksternal control mengacu pada keyakinan bahwa suatu kejadian tidak memiliki hubungan langsung dengan tindakan yang telah dilakukan oleh dirinya sendiri dan berada di luar kontrol dirinya.

\section{Karakter Wirausaha}

Menurut Baharuddin, (2009) karakter adalah suatu keadaan jiwa yang tampak dalam tingkah laku dan perbuatan sebagai akibat pengaruh pembawaan dan lingkungan. Dengan kata lain, karakter tergantung pada kekuatan dari luar (eksogen). Jadi, karakter individu dipengaruhi oleh pembawaan dan lingkungan. Karakter dapat diubah dan dididik. Pada umumnya seorang wirausaha adalah mereka yang berpotensi untuk berprestasi dan mempunyai motivasi yang besar untuk maju. Menurut Meredith, (2002), para wirausaha adalah individu-individu yang berorientasi pada tindakan, dan mempunyai motivasi tinggi dalam mengambil resiko untuk mengejar tujuannya. Sedangkan menurut (Wahyudi, 2012) terdapat tujuh definisi karakteristik wirausaha, yaitu: 1) Passion, 2) Independent, 3) Market sensitivity, 4) Creative \& Innovative, 5) Calculated risk taker, 6) presistent, 7) high ethical standart. Sedangkan menurut (Longenecker, 2001) kategori umum wirausaha memperluas karakteristik, seperti tingginya kebutuhan, keinginan mengambil resiko, percaya diri yang kuat, dan kemauan berbisnis. Menurut Mudjiarto, (2006) ada 9 karakteristik utama yang terdapat pada diri seorang wirausaha sebagai berikut: 1) dorongan berprestasi, artinya seseorang mempunyai keinginan besar untuk mencapai suatu prestasi. 2) bekerja keras, sebagian besar wirausaha "mabuk kerja" untuk mencapai apa yang ingin dicita-citakan. 3) memperhatikan kualitas: seorang wirausaha menangani dan mengawasi usahanya sendiri sampai mandiri, sebelum ia mulai dengan usaha baru lagi. 4) sangat bertanggungjawab: mampu bertanggungjawab pada usahanya, baik secara moral, legal maupun mental. 5) berorientasi pada imbalan: seorang wirausaha akan mengharapkan imbalan yang sepadan dengan usahanya. Imbalan bukan hanya soal uang, namun juga pengakuan dan penghormatan. 6) optimis: wirausaha hidup dengan anggapan semua waktu baik untuk bisnis, dan segala sesuatu mungkin. 7) berorientasi pada hasil karya yang baik (excellence oriented): seorang wirausaha ingin mencapai sukses yang menonjol.

Wirausahawan adalah seorang inovator dan kreator, yang disebut juga sebagai individu

yang mempunyai naluri untuk melihat peluang-peluang, mempunyai visi, mempunyai semangat, kemampuan baik dari segi mental maupun fisik, dan pemikiran yang kritis dan kreatif untuk menaklukan cara berpikir lamban dan malas (Alma, 2013). Baygrave dalam (Alma, 2013) menggambarkan beberapa karakteristik wirausahawan yang berhasil memiliki sifat-sifat yang dikenal dengan istilah $10 \mathrm{D}$, antara lain:1) visi (dream), 2) aktif membuat keputusan (decisiveness), 3) pelaku (doers), 4) penentuan (determination), 5) pendidikan (dedication), 6) kesetiaan (devotion), 7) detail, 8) tujuan (destiny), 9) kekayaan (dollar) dan 10) distribusi (distribute). Krakteristik-karakteristik tersebut merupakan karakter seorang wirausahawan yang mencerminkan sikap dan tindakannya, selain itu ada pendapat lain tentang karakteristik wirasahawan. Menurut Basrowi, (2011), karakteristik wirausaha yang perlu dimiliki dan dikembangkan, antara lain: berwatak luhur, kerja keras dan disiplin, mandiri dan realistis, prestatif dan komitmen tinggi, berpikir positif dan bertanggung jawab, dapat 
mengendalikan emosi, tidak ingkar janji, menepati janji, dan waktu, belajar dari pengalaman, memperhitungkan risiko, merasakan kebutuhan orang lain, bekerja sama dengan orang lain, menghasilkan sesuatu untuk orang lain, memberi semangat orang lain, mencari jalan keluar bagi setiap permasalahan dan merencanakan sesuatu sebelum bertindak.

\section{METODE PENELITIAN}

Penelitian ini termasuk jenis penelitian asosiatif, karena penelitian ini dirancang untuk mencari pengaruh pendidikan kewirausahaan $\left(\mathrm{X}_{1}\right)$, self efficacy $\left(\mathrm{X}_{2}\right)$ Locus of Control $\left(\mathrm{X}_{3}\right)$ dan karakter wirausaha $\left(\mathrm{X}_{4}\right)$ pada minat berwirausaha $(\mathrm{Y})$ di mahasiswa S1 Pada Universitas Muhammadiyah Sumatera Utara Di Kota Medan. Subjek penelitian ini adalahan mahasiswa Strata 1 jurusan Manajemen semester 7 yang sudah pernah menempuh mata kuliah kewirausahaan dan objek peneliatan ini adalah Minat berwirausaha mahasiswa. Populasi yang digunakan dalam penelitian ini adalah Mahasiswa/Mahasiswi Program Studi Manajemen Fakultas Ekonomi dan Bisnis semester 7 Universitas Muhammadiyah Sumatera Utara yang jumlahnya sebanyak 449 orang (feb.umsu.ac.id). Menurut Arikunto, (2013) jika peneliti memiliki populasi lebih dari 100, maka peneliti dapat menentukan kurang lebih $25 \%$ - 30\% dari jumlah tersebut. Sampel pada penelitian ini diambil 28\% dari jumlah populasi yaitu sebanyak 125 Orang. Pengumpulan data yang akan dilakukan, yaitu dengan cara mengidentifikasi masalah yang dihadapi oleh para mahasiswa untuk menjadi entrepreneur dengan melakukan penyebaran kuesioner kepada Mahasiswa/Mahasiswi Program Studi Manajemen Fakultas Ekonomi dan Bisnis Semester 7 yang sudah menerima mata kuliah kewirausahaan Universitas Muhammadiyah Sumatera Utara di kota Medan. Teknik analisis data dengan analisis regresi berganda yang digunakan untuk menentukan hubungan sebab akibat antara variabel bebas, yaitu pendidikan kewirausahaan, self efficacy, Locus of Control berpengaruh pada niat berwirausaha.

\section{HASIL DAN PEMBAHASAN}

\section{Uji Asumsi Klasik}

Uji normalitas digunkan untuk mengetahui apakah variabel independen dan variabel dependen atau keduanya berdistribusi normal atau tidak.

Untuk menguji normalitas data pada penelitian ini, dapat dilihat pada tabel IV.3 dibawah ini :

Tabel 2. Uji Normalitas Data One-Sample Kolmogorov-Smirnov Test

\begin{tabular}{llr}
\hline & & Unstandardized Residual \\
\hline Normal Parameters & & 125 \\
\hline Most Extreme Differences & Mean &, 0000000 \\
\cline { 2 - 3 } & Std. Deviation & 6,48317965 \\
\cline { 2 - 3 } & Absolute &, 069 \\
\cline { 2 - 3 } & Positive &, 042 \\
\cline { 2 - 3 } Kolmogative &,- 069 \\
\hline Asymp. Sig. (2-tailed) &, 069 \\
\hline a. Test distribution is Normal. &, $200^{\mathrm{C}, \mathrm{a}}$ \\
\hline b. Calculated from data. & \\
\hline c. Lilliefors Significance Correction. & \\
\hline d. This is a lower bound of the true significance. &
\end{tabular}

Dari hasil pengolahan data pada tabel diatas, diperoleh besarnya nilai Kolmogorov-Smirnov adalah 0,069 dan signifikan pada 0,200. Nilai signifikansi lebih besar dari 0,05 maka dapat diartikan data residual tersebut berdistribusi normal. maka dapat disimpulkan bahwa analisis lebih lanjut dapat dilakukan dengan menggunakan model regresi berganda. 


\section{Uji Multikolinearitas}

Uji multikolinearitas bertujuan untuk menguji apakah terdapat kolerasi antara variabel independen dalam model regresi (Juliandi, Irfan, \& Manurung, 2015). Jika pada model regresi terjadi multikolinearitas, maka koefisien regresi tidak dapat ditaksir dan nilai standard errormenjadi tidak terhingga. Untuk melihat ada atau tidaknya multikolinearitas dalam model regresi dapat dilihat dari :

1. Nilai tolerance dan lawannya

2. Variance Inflation factor (VIC)

Kedua ukuran ini menunjukkan setiap variabel independen manakah yang dijelaskan oleh vvariabel independen lainnya. Tolerance mengukur variabilitas variabel independen yang terpilih yang tidak dijelaskan oleh variabel independen lainnya. Jadi, nilai tolerance yang rendah sama dengan nilai VIF yang tinggi (karena VIF $=1$ / tolerance). Nilai cutoff yang umum dipakai untuk menunjukkan adanya multikolinearitas adalah nilai tolerance $<0,10$ atau sama dengan VIF > 10. HasiL dari uji multikolinearitas dapat dilihat pada tabel berikut :

Tabel 3. Hasil Uji Multikolinearitas

\begin{tabular}{lllr}
\hline \multirow{2}{*}{ Model } & & \multicolumn{2}{c}{ Collinearity Statistics } \\
\cline { 2 - 4 } & & \multicolumn{2}{c}{ Tolerance } \\
& (Constant) &, 971 & \\
\cline { 2 - 4 } & Pendidikan Kewirausahaan &, 487 & 1,030 \\
\cline { 2 - 4 } & Self Efficacy &, 759 & 2,051 \\
\cline { 2 - 4 } & Locus of Control &, 402 & 1,317 \\
\cline { 2 - 4 } & Karakter Wirausaha & & 2,491 \\
\hline
\end{tabular}

Dari data pada taabel diatas dapat diketahui bahwa bilai Variance Inflation Factor (VIF) untuk variabel pendidikan kewirausahaan sebesar 1,030, self efficacy sebesar 2,051, Locus of Control sebesar 1,317 dan karakter wirausaha sebesar 2,491. Demikian juga dengan nilai Tolerance pada pendidikan kewirausahaan sebesar 0,971, self efficacy sebesar 0,487, Locus of Control sebesar 0,759 dan karakter wirausaha sebesar 0,402 dari masing-masing variabel ini tolerance lebih besar dari 0,1 sehingga dapat disimpulkan bahwa tidak terjadi gejala multikolinearitas antara variabel independen yang diindikasikan dari nilai tolerance setiap variabel independen lebih besar dari 0,1 dan nilai VIF lebih kecil dari 10, maka dapat disimpulkan bahwa analisis lebih lanjut dapat dilakukan dengan menggunakan model regresi berganda.

\section{Uji Heterokedastisitas}

Uji heterokedastistas bertujuan menguji apakah dalam model regresi terjadi ketidaksamaan variance dari residual pengamatan ke pengamatan lain. Model regresi yang baik adalah tidak terjadi heterokedastistas. Alat uji yang digunakan untuk mengukur gejala heteroskedastisitas adalah Uji Glejser. Menurut (Juliandi, Irfan, \& Manurung, 2014), model regresi yang baik ialah yang tidak mengandung gejala heteroskedatisitas dinyatakan tidak akan, jika nilai signifkansi lebih besar dari alpha 0,05.

\section{Tabel 4. Uji Heterokedastisitas}

\begin{tabular}{lr}
\hline \multicolumn{1}{c}{ Model } & Sig. \\
\hline (Constant) &, 025 \\
\hline Pendidikan Kewirausahaan &, 057 \\
\hline Self Efficacy &, 140 \\
\hline Locus of Control &, 094 \\
\hline Karakter Wirausaha &, 174 \\
\hline
\end{tabular}


Hasil uji heteroskedesitas menunjukan bahwa nilai Sig. dari variabel Pendidikan Kewirausahaan $\left(\mathrm{X}_{1}\right)$, Self Eficacy $\left(\mathrm{X}_{2}\right)$, Locus of Control $\left(\mathrm{X}_{3}\right)$ dan Karakter Wirausaha $\left(\mathrm{X}_{4}\right)$ sebesar 0,057, 0,140, 0,094 dan 0,174 yang artinya niali variabel lebih besar dari 0,05 yang berarti tidak terdapat pengaruh antara variabel bebas terhadap absolute residual. Dengan demikian, model yang dibuat tidak mengandung gejala heteroskedastisitas. maka dapat disimpulkan bahwa analisis lebih lanjut dapat dilakukan dengan menggunakan model regresi berganda.

\section{Uji Regresi Linier Berganda}

Dalam menganalisis data digunakan analisis regresi linear berganda. Dimana analisis berganda untuk mengetahui pengaruh dari masing-masing variabel bebas terhadap variabel terikat. Berikut hasil pengolahan data dengan menggunakan SPSS versi 22.0.

Tabel 5. Koefisien Regresi

\begin{tabular}{|c|c|c|c|c|}
\hline \multirow{2}{*}{\multicolumn{2}{|c|}{ Model }} & \multicolumn{2}{|c|}{ Unstandardized Coefficients } & \multirow{2}{*}{$\begin{array}{c}\begin{array}{c}\text { Standardized } \\
\text { Coefficients }\end{array} \\
\text { Beta }\end{array}$} \\
\hline & & $\mathrm{B}$ & Std. Error & \\
\hline 1 & (Constant) & $-4,564$ & 5,487 & \\
\hline & Pendidikan Kewirausahaan &, 073 & , 143 & ,025 \\
\hline & Self Efficacy &, 751 & ,105 & ,486 \\
\hline & Locus of Control & 158 & ,098 & , 087 \\
\hline & Karakter Wirausaha & ,479 & ,090 & ,397 \\
\hline
\end{tabular}

a. Dependent Variable: total.y

Berdasarkan data yang diperoleh dari uji regresi berganda maka diketahui nilai-nilai sebagai berikut :

$$
\begin{array}{ll}
\text { konstanta } & =-4,564 \\
\mathrm{X}_{1} & =0,073 \\
\mathrm{X}_{2} & =0,751 \\
\mathrm{X}_{3} & =0,158 \\
\mathrm{X}_{4} & =0,479
\end{array}
$$

Hasil tersebut dimasukkan kedalam persamaan regresi linier berganda sehingga diketahui persamaan berikut :

\section{$Y=-4,564+0,073 X 1+0,751 \times 2+0,153 X 3+0,479 X 4$}

Koefisien regresi menunjukan bahwa setiap variabel independen yang diuji berpengaruh positif terhadap variabel dependen.

1) Konstanta -4,564 berarti jika Pendidikan kewirausahaan, Self Efficacy,Locus Of Contol, dan Karakter wirausaha 0 maka minat berwirausaha mahasiswa adalah -4,564

2) Koefisien regresi pendidikan kewirasuahaan 0,073 yang berarti setelah mandapatkan 1 kali pendidikan kewirausahaan minat untuk berwirausaha akan semakin meningkat sebesar 0,073 .

3) Koefisien regresi self efficacy 0,751 yang Berarti jika self efficacy yang dimiliki mahasiswa naik 1, maka minat mahasiswa untuk berwirausaha semakin meningkat sebanyak 0,751.

4) Koefisien regresi Locus of Control 0,153 yang menunjukan bahwa jika Locus of Control yang dimiliki mahasiswa naik 1 , maka minat mahasiswa untuk berwirausaha semakin meningkat sebanyak 0,153.

5) Koefisien regresi Karakter wirausaha 0,479 yang menunjukan bahwa jika Karakter wirausaha yang dimiliki mahasiswa naik 1, maka minat mahasiswa untuk berwirausaha semakin meningkat sebnyak 0,479 . 


\section{Uji Hipotesis}

\section{Uji Signifikan Parsial (Uji Statistik t)}

Uji $\mathrm{t}$ dipergunakan dalam penelitian ini untuk mengetahui kemampuan dari masing-masing variabel independen dalam mempengaruhi variabel dependen. Alasan lain uji $t$ dilakukan yaitu untuk menguji apakah varoabel bebas (X) secara individual terdapat hubungan yang signifikan atau tidak terhadap variabel terikat. Untuk penyederhanaan uji statistik t diatas penulis menggunakan pengolahan data SPSS for windows versi 22,0 maka dapat diperoleh hasil uji t sebagai berikut :

\section{Tabel 6. Uji Parsial (Uji-t)}

\begin{tabular}{|c|c|c|c|c|c|c|}
\hline \multirow{2}{*}{\multicolumn{2}{|c|}{ Model }} & \multicolumn{2}{|c|}{$\begin{array}{l}\text { Unstandardized } \\
\text { Coefficients }\end{array}$} & $\begin{array}{c}\text { Standardized } \\
\text { Coefficients }\end{array}$ & \multirow[b]{2}{*}{$\mathrm{T}$} & \multirow[b]{2}{*}{ Sig. } \\
\hline & & $\mathrm{B}$ & Std. Error & Beta & & \\
\hline 1 & (Constant) & $-4,564$ & 5,487 & &,- 832 & ,407 \\
\hline & $\begin{array}{l}\text { Pendidikan } \\
\text { kewirausahaan }\end{array}$ & 073, & 143, & ,025, & ,512 & 610 \\
\hline & Self efficacy & ,751 & , 105 & ,486 & 7,167 &, 000 \\
\hline & Locus of Control & ,158 & ,098 & ,087 & 1,607 &, 111 \\
\hline & Karakter wirausaha & 479 &, 090 & ,397 & 5,319 &, 000 \\
\hline
\end{tabular}

a. Dependent Variable: total.y

Hasil penelitian statistik t pada tabel diatas dapat dijelaskan sebagai berikut :

Berdasarkan hasil pengujian parsial pengaruh antara Pendidikan Kewirausahaan terhadap Minat Berwirausaha diperoleh $\mathrm{t}_{\text {hitung }}$ adalah 0.512 dan $\mathrm{t}_{\text {tabel }}$ dengan $\alpha=5 \%$ diketahui sebesar 1.980, dengan tingkat signifikan $0,610>0,05$. Dari hasil tersebut dapat disimpulkan bahwa $\mathrm{H}_{\mathrm{o}}$ diterima $\left(\mathrm{H}_{\mathrm{a}}\right.$ ditolak), hal ini menunjukkan bahwa terdapat pengaruh namun tidak signifikan antara Pendidikan Kewirausahaan terhadap Minat Berwirausaha pada mahasiswa Strata 1 Program Studi Manajemen Fakultas Ekonomi dan Bisnis Universitas Muhammadiyah Sumatera Utara.

Berdasarkan hasil pengujian parsial pengaruh antara Self Efficacy terhadap Minat Berwirausaha diperoleh $t_{\text {hitung }}$ adalah 7.167 dan $t_{\text {tabel }}$ dengan $\alpha=5 \%$ diketahui sebesar 1.980, dengan tingkat signifikan $0,000<0,05$. Dari hasil tersebut dapat disimpulkan bahwa $\mathrm{H}_{\mathrm{o}}$ ditolak $\left(\mathrm{H}_{\mathrm{a}}\right.$ diterima), hal ini menunjukkan bahwa ada pengaruh yang signifikan antara Self Efficacy terhadap Minat Berwirausaha pada mahasiswa Strata 1 Program Studi Manajemen Fakultas Ekonomi dan Bisnis Universitas Muhammadiyah Sumatera Utara.

Berdasarkan hasil pengujian parsial pengaruh antara Locus of Control terhadap Minat Berwirausaha diperoleh $t_{\text {hitung }}$ adalah 1.607 dan $t_{\text {tabel }}$ dengan $\alpha=5 \%$ diketahui sebesar 1.980, dengan tingkat signifikan 0,111>0,05. Dari hasil tersebut dapat disimpulkan bahwa $\mathrm{H}_{\mathrm{o}}$ diterima $\left(\mathrm{H}_{\mathrm{a}}\right.$ ditolak), hal ini menunjukkan bahwa terdapat pengaruh namun tidak signifikan antara Locus of Control terhadap Minat Berwirausaha pada mahasiswa Strata 1 Program Studi Manajemen Fakultas Ekonomi dan Bisnis Universitas Muhammadiyah Sumatera Utara.

Berdasarkan hasil pengujian parsial pengaruh antara Karakter Wirausaha terhadap Minat Berwirausaha diperoleh $t_{\text {hitung }}$ adalah 4.794 dan $t_{\text {tabel }}$ dengan $\alpha=5 \%$ diketahui sebesar 1.980, dengan tingkat signifikan $0,000<0,05$. Dari hasil tersebut dapat disimpulkan bahwa $\mathrm{H}_{\mathrm{o}}$ ditolak $\left(\mathrm{H}_{\mathrm{a}}\right.$ diterima), hal ini menunjukkan bahwa ada pengaruh yang signifikan Karakter Wirausaha terhadap Minat Berwirausaha pada mahasiswa Strata 1 Program Studi Manajemen Fakultas Ekonomi dan Bisnis Universitas Muhammadiyah Sumatera Utara.

\section{Uji Simultan (Uji F)}

Uji simultan ini digunakan untuk mengetahui apakah variabel bebas secara bersama-sama berpengaruh secara signifikan terhadap variabel terikat. Berdasarkan hasil 
pengolahan data dengan menggunakan program SPSS Versi 22.0, maka diperoleh hasil sebagai berikut :

Tabel 6. Hasil Uji Simultan (Uji-F)

\begin{tabular}{llrrrrr}
\hline \multicolumn{7}{c}{ ANOVA $^{\mathbf{a}}$} \\
\hline Model & Sum of Squares & Df & Mean Square & F & Sig. \\
\hline 1 & Regression & 14164,351 & 4 & 3541,088 & 81,531 &, $000^{\circ}$ \\
\cline { 2 - 7 } & Residual & 5211,921 & 120 & 43,433 & & \\
\cline { 2 - 7 } & Total & 19376,272 & 124 & & & \\
\hline
\end{tabular}

Dapat dilihat dari hasil diatas nilai sig $\mathrm{F}<0,05(0,000<0,05)$ dan $\mathrm{F}$ hitung $>\mathrm{F}$ tabel $(81,531>2,447)$, maka $\mathrm{H}_{0}$ ditolak. Jadi terdapat pengaruh positif dan signifikan pengetahuan kewirausahaan, self efficacy, Locus of Control dan karakter wirausaha secara bersama-sama terhadap minat berwirausaha pada mahasiswa Strata 1 Program Studi Manajemen Fakultas Ekonomi dan Bisnis Universitas Muhammadiyah Sumatera Utara.

\section{Koefisien Determinasi}

Koefisien determinasi ini berfungsi untuk mengetahui persentase besarnya pengaruh variabel independen dan variabel dependen yaitu dengan mengkuadratkan koefisien yang ditemukan. Dalam penggunaanya, koefisien determinasi ini dinyatakan dalam persentase pengaruh Pendidikan Kewirausahaan, Self Efficacy, Locus of Control dan karakter wirausaha terhadap Minat Berwirausaha maka dapat diketahui uji determinasi.

\section{Tabel 7. Koefisien Determinasi}

\begin{tabular}{lrrrr}
\hline & & & \multicolumn{3}{c}{ Std. Error of the } \\
Model & $\mathrm{R}$ & $\mathrm{R}$ Square Adjusted R Square & Estimate \\
\hline 1 &, $855^{\mathrm{a}}$ &, 731 & 722 & 6,590 \\
\hline
\end{tabular}

Pada tabel diatas dapat dilihat hasil analisis regresi secara keseluruhan menunjukkan nilai R Square sebesar 0,731. Nilai Adjusted R Square $\left(R^{2}\right)$ atau koefisien determinasi adalah sebesar 0,731. Angka ini mengidentifikasikan bahwa Minat Berwirausaha (variabel dependen) mampu dijelaskan oleh Pendidikan Kewirausahaan, Self Efficacy, Locus of Control dan karakter wirausaha. Kemudian standard error of the estimate adalah sebesar 6,590 atau 6,59 dimana semakin kecil angka ini akan membuat model regresi semakin tepat dalam memprediksi minat berwirausaha.

\section{Pembahasan}

\section{Pengaruh Pendidikan Kewirausahaan Terhadap Minat Berwirausaha}

Tujuan yang pertama dari penelitian ini adalah untuk menganalisis pengaruh pendidikan kewirausahaan pada minat berwirausaha mahasiswa S1 Fakultas Ekonomi dan Bisnis Universitas Muhammadiyah Sumatera Utara. Berdasarkan hasil pengujian parsial pengaruh antara Pendidikan Kewirausahaan terhadap Minat Berwirausaha diperoleh $\mathrm{t}_{\text {hitung }}$ adalah 0.512 dan $t_{\text {tabel }}$ dengan $\alpha=5 \%$ diketahui sebesar 1.980, dengan tingkat signifikan 0,610 >0,05. Dari hasil tersebut dapat disimpulkan bahwa $\mathrm{H}_{\mathrm{o}}$ diterima $\left(\mathrm{H}_{\mathrm{a}}\right.$ ditolak), hal ini menunjukkan bahwa terdapat pengaruh namun tidak signifikan antara Pendidikan Kewirausahaan terhadap Minat Berwirausaha pada mahasiswa Strata 1 Program Studi Manajemen Fakultas Ekonomi dan Bisnis Universitas Muhammadiyah Sumatera Utara. Ini menunjukan bahwa ada kekurangan dalam metode ataupun sistem penyampaian materi pembelajaran pendidikan kewirausahaan yang disampaikan dosen kepada mahasiswa.

Hasil penelitian sejalan dengan yang ditemukan dari penelitian (Indarti \& Rostiani, 2008) menunjukkan bahwa mahasiswa yang berlatar belakang pendidikan ekonomi dan bisnis justru 
mempunyai intensi kewirausahaan yang lebih rendah, temuan ini bertolak belakang dari penelitian-penelitian sebelumnya. Penelitian ini didukung dengan hasil penelitian dari (Septiana, 2014) menunjukkan pengaruh positif namun tidak signifikan pemahaman mahasiswa dalam pembelajaran kewirausahaan terhadap minat berwirausaha mahasiswa.

\section{Pengaruh Self Efficacy Terhadap Minat Berwirausaha}

Tujuan yang kedua dari penelitian ini adalah untuk menganalisis pengaruh self efficacy pada minat berwirausaha mahasiswa Program Studi Manajemen Fakultas Ekonomi dan Bisnis Universitas Muhammadiyah Sumatera Utara. Berdasarkan hasil pengujian parsial pengaruh antara Self Efficacy terhadap Minat Berwirausaha diperoleh $\mathrm{t}_{\text {hitung }}$ adalah 7.167 dan $\mathrm{t}_{\text {tabel }}$ dengan $\alpha=5 \%$ diketahui sebesar 1.980, dengan tingkat signifikan $0,000<0,05$. Dari hasil tersebut dapat disimpulkan bahwa $\mathrm{H}_{\mathrm{o}}$ ditolak $\left(\mathrm{H}_{\mathrm{a}}\right.$ diterima), hal ini menunjukkan bahwa ada pengaruh yang signifikan antara Self Efficacy terhadap Minat Berwirausaha pada mahasiswa Strata 1 Program Studi Manajemen Fakultas Ekonomi dan Bisnis Universitas Muhammadiyah Sumatera Utara. Hasil ini menunjukkan bahwa mahasiswa Universitas Muhammadiyah Sumatera Utara memiliki self efficacy yang tinggi untuk berwirausaha yang harus tetap dipertahankan dan ditingkatkan lagi. Hasil penelitian ini sejalan dengan rumusan hipotesis yang menyatakan self efficacy berpengaruh positif terhadap minat berwirausaha. Hasil penelitian ini menunjukan bahwa semakin tinggi self efficacy yang dimiliki mahsiswa, maka minat mahasiswa untuk berwirausaha semakin tinggi. Hasil penelitian ini konsisten dengan (Nursito \& Nugroho, 2013) yang sebelumnya juga telah membuktikan bahwa, self efficacy berpengaruh positif dan signifikan terhadap minat berwirausaha. Hasil penelitian ini sesuai dengan teori yang diungkapkan oleh (Cromie, 2000) yang menjelaskan bahwa self efficacy mempengaruhi kepercayaan sesaorang pada tercapai atau tidaknya tujuan yang sudah ditargetkan. Semakin tinggi kepercayaan diri seorang mahasiswa atas kemampuan dirinya untuk dapat berusaha, maka semakin besar pula keinginannya untuk menjadi seorang wirausaha.

\section{Pengaruh Locus of Control Terhadap Minat Berwirausaha}

Tujuan yang terakhir dari penelitian ini adalah untuk menganalisis pengaruh Locus of Control pada minat berwirausaha mahasiswa Program Studi Manajemen Fakultas Ekonomi dan Bisnis Universitas Muhammadiyah Sumatera Utara. Berdasarkan hasil pengujian parsial pengaruh antara Locus of Control terhadap Minat Berwirausaha diperoleh $t_{\text {hitung }}$ adalah 1.607 dan $\mathrm{t}_{\text {tabel }}$ dengan $\alpha=5 \%$ diketahui sebesar 1.980, dengan tingkat signifikan $0,111>0,05$. Dari hasil tersebut dapat disimpulkan bahwa $\mathrm{H}_{\mathrm{o}}$ diterima ( $\mathrm{H}_{\mathrm{a}}$ ditolak), hal ini menunjukkan bahwa terdapat pengaruh namun tidak signifikan antara Locus of Control terhadap Minat Berwirausaha pada mahasiswa Strata 1 Program Studi Manajemen Fakultas Ekonomi dan Bisnis Universitas Muhammadiyah Sumatera Utara. Hasil ini menjelaskan bahwa control of locus yang dimiliki mahasiswa Universitas Muhammadiyah Sumatera Utara masih rendah dan harus diperbaiki. Hasil ini sama dengan penelitian (Bustan, 2014) yang menemukan bahwa variabel Locus of Control tidak mempengaruhi minat mahasiswa untuk berwirausaha. Hasil penelitian ini menunjukan bahwa semakin tinggi locus of control yang dimiliki mahasiswa, maka minat mahasiswa untuk berwirausaha semakin tinggi. Hasil penelitian ini tidak sejalan dengan dengan hasil penelitian (Sinurat, Aini, \& Makmur, 2018) dan (Primandaru, 2017) yang sebelumnya juga telah membuktikan bahwa, locus of control berpengaruh positif dan signifikan terhadap minat berwirausaha.

\section{Pengaruh Karakter Wirausaha terhadap Minat Berwirausaha}

Tujuan yang terakhir dari penelitian ini adalah untuk menganalisis pengaruh karakter wirausaha pada minat berwirausaha mahasiswa Program Studi Manajemen Fakultas Ekonomi 
dan Bisnis Universitas Muhammadiyah Sumatera Utara. Berdasarkan hasil pengujian parsial pengaruh antara Karakter Wirausaha terhadap Minat Berwirausaha diperoleh $t_{\text {hitung }}$ adalah 4.794 dan $t_{\text {tabel }}$ dengan $\alpha=5 \%$ diketahui sebesar 1.980, dengan tingkat signifikan 0,000 $<0,05$. Dari hasil tersebut dapat disimpulkan bahwa $\mathrm{H}_{\mathrm{o}}$ ditolak $\left(\mathrm{H}_{\mathrm{a}}\right.$ diterima), hal ini menunjukkan bahwa ada pengaruh yang signifikan Karakter Wirausaha terhadap Minat Berwirausaha pada mahasiswa Strata 1 Program Studi Manajemen Fakultas Ekonomi dan Bisnis Universitas Muhammadiyah Sumatera Utara. Hasil ini menunjukkan bahwa mahasiswa Universitas Muhammadiyah Sumatera Utara memiliki karakter wirausaha yang tinggi yang harus di pertahankan dan terus ditingkatkan. Hasil penelitian ini sesuai dengan hasil penelitian yang dilakukan oleh (Septiana, 2014) yang menyimpulkan bahwa terdapat pengaruh positif dan signifikan karakter wirausaha mahasiswa terhadap minat berwirausaha mahasiswa.

\section{Pengaruh Pendidikan Kewirausahaan, Self Efficacy, Locus of Control dan Karakter Wirausaha terhadap Minat Berwirausaha}

Hasil penelitian yang diperoleh mengenai Pengaruh Pendidikan Kewirausahaan, Self Efficacy, Locus of Control dan Karakter Wirausaha terhadap Minat Berwirausaha pada mahasiswa strata 1 semester 7 Program Studi Manajemen Fakultas Ekonomi dan Bisnis Universitas Muhammadiyah Sumatera Utara. Dari uji ANOVA (Analysis Of Variance) pada tabel IV.13 didapat $\mathrm{f}_{\text {hitung }}$ sebesar 81,531 dengan tingkat signifikan sebesar 0,000. Sedangkan $\mathrm{f}_{\text {tabel }}$ dengan tingkat signifikan $\alpha=5 \%$ adalah 2.450. Berdasarkan hal tersebut bahwa $\mathrm{f}_{\text {hitung }}>$ $\mathrm{f}_{\text {tabel }}(81.531>2.450) \mathrm{H}_{\mathrm{o}}$ ditolak $\left(\mathrm{H}_{\mathrm{a}}\right.$ diterima). Jadi dapat disimpulkan bahwa variabel Pendidikan Kewirausahaan, Self Efficacy, Locus of Control dan Karakter Wirausaha, secara bersama-sama berpengaruh positif dan signifikan terhadap terhadap minat berwirausaha mahasiswa. Hasil penelitian ini sejalan dengan hasil penelitian dari (Dusak \& Sudiksa, 2016) (Anggraeni \& Nurcaya, 2016) menunjukkan bahwa variabel Pendidikan Kewirausahaan, Self Efficacy, Locus of Control dan Karakter Wirausaha, secara bersama-sama berpengaruh positif dan signifikan terhadap minat berwirausaha.

Berdasarkan hasil penelitian yang dilakukan penulis serta teori, pendapat, maupun penelitian terdahulu yang telah dikemukakan diatas mengenai pengaruh Pendidikan Kewirausahaan, Self Efficacy, Locus of Control dan Karakter Wirausaha, secara bersama-sama berpengaruh, secara bersama-sama pengaruh terhadap minat berwirausaha mahasiswa. Maka penulis dapat menyimpulkan bahwa ada kesesuaian antara hasil penelitian dengan teori, pendapat dan penelitian terdahulu yakni ada pengaruh signifikan Pendidikan Kewirausahaan, Self Efficacy, Locus of Control dan Karakter Wirausaha, secara bersama-sama berpengaruh, secara bersama-sama pengaruh terhadap minat berwirausaha mahasiswa.

\section{KESIMPULAN}

Berdasarkan data yang diperoleh dari hasil analisis yang dilakukan maka dapat ditarik kesimpulan bahwa secara simultan, terdapat pengaruh positif dan signifikan pendidikan kewirausahaan, self efficacy, Locus of Control dan karakter wirausaha terhadap minat berwirausaha. Secara parsial pendidikan kewirausahaan dan Locus of Control tidak berpengaruh signfikan terhadap minat berwirausaha. Secara parsial self efficacy dan karakter wirausaha berpengaruh signifikan terhadap minat berwirausaha mahasiswa Program Studi Manajemen Fakultas Ekonomi dan Bisnis Universitas Muhammadiyah Sumatera Utara. Berdasarkan hasil penelitian yang telah dilakukan, maka saran yang dapat diberikan adalah meningkatkan metode pengajaran, memberi pelatihan, sehingga setelah mendapatkan pengetahuan mahasiswa berminat untuk berwirausaha, membentuk jaringan dengan wirausahawan muda dengan stakeholder lokal yang memiliki program kewirausahaan yang 
dapat memberi tahu mahasiswa tentang peluang dan tantangan yang akan dihadapi dimasa depan sehingga dapat membentuk self efficacy dan Locus of Control mahasiswa agar lebih meningkat serta dapat memicu minat berwirausaha mahasiswa. Untuk mewujudkan dan meningkatkan minat berwirausaha disarankan mengembangkan program pendidikan kewirausahaan tidak hanya memberikan teori, tetapi lebih membahas studi kasus tentang para wirausahawan dalam memulai usahanya dan menyusun strategi apa yang sesuai untuk wirausahawan tersebut untuk menghadapi tantangan dimasa akan datang yang membuat mahasiswa mendapatkan pengetahuan yang lebih dalam lagi dan membentuk karakter yang lebih kuat untuk menjadi wirausaha.

\section{DAFTAR PUSTAKA}

Abror, A. R. (2013). Psikologi Pendidikan. Yogyakarta: PT Tiara Wacana.

Alma, B. (2013). Kewirausahaan. Bandung: Alfabeta.

Alwisol. (2009). Psikologi Kepribadian. Malang: UMM Press.

Anggraeni, D. A. L., \& Nurcaya, I. N. (2016). Peran Efikasi Diri Dalam Memediasi Pengaruh Pendidikan Kewirausahaan Terhadap Niat Berwirausaha. E- Jurnal Manajemen Unud, 5(4), 2424-2453.

Arikunto, S. (2013). Prosedur Penelitian: Suatu Pendekatan Praktik. Jakarta: Rineka Cipta.

Baharuddin, B. (2009). Pendidikan dan Psikologi Perkembangan. Yogyakarta: ArRuzz Media.

Bandura, A. (2009). Cultivate Self - effi cacy for Personal and Organizational Effectiveness. In Handbook of Principles of Organizational Behavior: Indispensable Knowledge for Evidence-Based Management (pp. 179-200). New York: Wiley. https://doi.org/10.1002/9781119206422.ch10

Baron, R. A., \& Byrne, D. (2004). Psikologi Sosial. Jakarta: Erlangga.

Basrowi, B. (2011). Kewirausahaan Untuk Perguruan Tinggi. Bogor: Ghalia Indonesia.

Bustan, J. (2014). Pengaruh prestasi, locus of control, risiko, toleransi ambiguitas, percaya diri, dan inovasi terhadap minat berwirausaha mahasiswa. Orasi Bisnis: Jurnal Ilmiah Administrasi Niaga, 11(1), 60-67.

Chen, C. C., Greene, P. G., \& Crick, A. (1998). Does entrepreneurial self-efficacy distinguish entrepreneurs from managers? Journal of Business Venturing, 13(4), 295-316. https://doi.org/10.1016/S0883-9026(97)00029-3

Chen, W., Weng, C. S., \& Hsu, H. (2010). A study of the entrepreneurship of Taiwanese youth by the Chinese Entrepreneur Aptitude Scale. Journal of Technology Management in China, 5(1), 26-39. https://doi.org/10.1108/17468771011032778

Cheng, M. Y., Chan, W. S., \& Mahmood, A. (2009). The effectiveness of entrepreneurship education in Malaysia. Education and Training, 51(7), 555-566. https://doi.org/10.1108/00400910910992754

Chimucheka, T. (2013). The Impact of Entrepreneurship Education on the Establishment and Survival of Small, Micro and Medium Enterprises (SMMEs). Journal of Economics, 4(2), 157-168. https://doi.org/10.1080/09765239.2013.11884975

Cromie, S. (2000). Assessing entrepreneurial inclinations: Some approaches and empirical evidence. European Journal of Work and Organizational Psychology, 9(1), 7-30. https://doi.org/10.1080/135943200398030

Dusak, I. K. A. F., \& Sudiksa, I. B. (2016). Pengaruh Pendidikan Kewirausahaan, Parental, dan Locus of Control Terhadap Niat Berwirausaha Mahasiswa. E-Jurnal Manajemen Unud, 5(8), 5184-5214.

Fatoki, O. (2014). The Entrepreneurial Intention of Undergraduate Students in South Africa: The Influences of Entrepreneurship Education and Previous Work Experience. 
Mediterranean Journal of Social Sciences, 5(7), 294-299.

Feist, J., Feist, G. J., \& Roberts, T.-A. (2013). Theories of Personality (8th ed.). California: McGraw-Hill Education.

Gaddam, S. (2008). Identifying the relationship between behavioral motives and entrepreneurial intentions: An empirical study based on the perceptions of business management students. The Icfaian Journal of Management Research, 7, 35-45.

Indarti, N., \& Rostiani, R. (2008). Intensi Kewirausahaan Mahasiswa: Studi Perbandingan Antara Indonesia, Jepang Dan Norwegia. Journal of Indonesian Economy and Business, 23(4), 369-384. https://doi.org/10.22146/jieb.6316

Isrososiawan, S. (2013). Peran Kewirausahaan Dalam Pendidikan. Society, Jurnal Jurusan Pendidikan IPS Ekonomi, 9(1), 26-49.

Juliandi, A., Irfan, \& Manurung, S. (2014). Metode Penelitian Bisnis. Medan: UMSU Press.

Juliandi, A., Irfan, \& Manurung, S. (2015). Metodologi Penelitian Bisnis Konsep dan Aplikasi. Medan: UMSU Press.

Kreitner, R., \& Kinicki, A. (2008). Organizational Behavior (8th ed.). Boston: McGraw - Hill. Kreitner, R., \& Kinicki, A. (2014). Perilaku Organisasi. Jakarta: Salemba Empat.

Lee-Kelley, L. (2006). Locus of control and attitudes to working in virtual teams. International Journal of Project Management, 24(3), 234-243. https://doi.org/10.1016/j.ijproman.2006.01.003

Longenecker, J. G. (2001). Kewirausahaan Manajemen Usaha Kecil. Jakarta: Salemba Empat. Luthans, F. (2010). Organizational behavior : An Evidence-Based Approach (12th ed.). New York: McGraw-Hill/Irwin.

Meredith, G. G. (2002). Kewirausahaan: Teori dan Praktek. Jakarta: PPM.

Mudjiarto, M. (2006). Membangun karakter dan kepribadian kewirausahaan. Yogyakarta: Graha Ilmu.

Mujiatun, S., Jufrizen, J., \& Ritonga, P. (2019). Model Kelelahan Emosional: Antaseden Dan Dampaknya Terhadap Kepuasan Kerja Dan Komitmen Organisasi Dosen. MIX: Jurnal Ilmiah Manajemen, 9(3), 447-465.

Mulyani, E. (2011). Model Pendidikan Kewirausahaan di Pendidikan Dasar dan Menengah. Jurnal Ekonomi Dan Pendidikan, 8(1), 1-18. https://doi.org/10.21831/jep.v8i1.705

Napitupulu, E. L. (2009). Kemampuan Berwirausaha Perlu Diciptakan. Retrieved from www.kompas.com

Nursito, S., \& Nugroho, A. J. S. (2013). Analisis Pengaruh Interaksi Pengetahuan Kewirausahaan Dan Efikasi Diri Terhadap Intensi Kewirausahaan. Kiat BISNIS, 5(3), 201-211.

Prihantoro, W. S. G. (2015). Pengaruh Pendidikan Kewirausahaan, Motivasi Berwirausaha Dan Lingkungan Keluarga Terhadap Sikap Mental Kewirausahaan Siswa Smk Negeri 1 Demak (Studi Pada Siswa Kelas XI Pemasaran Tahun Ajaran 2014/2015). Universitas Negeri Semarang.

Primandaru, N. (2017). Analisis Faktor-Faktor Yang Berpengaruh Pada Minat Berwirausaha Mahasiswa. Jurnal Economia, 13(1), 68-78.

Purwanto, N. (2007). Psikologi Pendidikan. Bandung: PT Remadja Rosdakarya.

Ramayah, T., \& Harun, Z. (2005). Entrepreneurial intention among the student of Universiti Sains Malaysia. International Journal of Management and Entrepreneurship, 1(1), 8-20.

Robbins, S. P. (2004). Teori organisasi, struktur, desain, dan aplikasi. New Jersey: Prentice Hall.

Robbins, Stephen P., \& Judge, T. A. (2011). Organizational Behavior (14th ed.). New Jersey: Prentice Hall. 
Rotter, J. B. (1990). Internal versus external control of reinforcement: A case history of a variable. American Psychologist, 45(4), 489-493. https://doi.org/10.1037/0003-066X.45.4.489

Septiana, D. (2014). Pengaruh Pembelajaran Kewirausahaan, Karakter Wirausaha, Dan Persepsi Tentang Program Kewirausahaan Terhadap Minat Berwirausaha. Jurnal Pendidikan Dan Ekonomi, 4(5).

Sinurat, J. P., Aini, Y., \& Makmur, M. (2018). Pengaruh Motivasi, Self Efficacy dan Locus of Control Terhadap Minat Berwirausaha. Cano Economos: Jurnal Ilmiah Fakultas Ekonomi, 7(1).

Slameto. (2010). Belajar dan Faktor- Faktor yang Mempengaruhinya. Jakarta: Rineka Cipta.

Suryana. (2013). Kewirausahaan: kiat dan proses menuju sukses. Jakarta: Salemba Empat.

Tedjasutisna, A. (2004). Kewirausahaan. Bandung: Armico.

Wahyudi, S. (2012). Entrepreneurial Branding and Selling, Road Map Menjadi Entrepreneur Sejat. Yogyakarta: Graha Ilmu.

Walgito, B. (2004). Pengantar Psikologi Umum. Yogyakarta: Andi.

Wibowo, S., \& Pramudana, K. A. S. (2016). Pengaruh Pendidikan Kewirausahaan Terhadap Intensi Berwirausaha Yang Dimediasi Oleh Sikap Berwirausaha. E-Jurnal Manajemen Unud, 5(12), 8167-8198.

Winkel, W. S. (2004). Psikologi Pendidikan dan Evaluasi Belajar. Jakarta: PT Gramedia Pustaka Utama.

Yusnandar, W. (2017). Analisis determinan minat berbisnis online di kalangan mahasiswa. Jurnal Riset Sains Manajemen, 1(2), 129-138. https://doi.org/10.5281/zenodo.1095037 